\title{
An Analytical Study on Entrepreneurial Activity as a tool for socio-economic development of Tribal Women in BTAD area of Assam
}

\author{
Gunajit Sarma. \\ Assistant Professor in Economics, Department of Humanities and Social Sciences, Central Institute of \\ Technology, Kokrajhar BTAD, Assam - 783370 (India) \\ gsecit.2009@rediffmail.com
}

\section{Introduction}

Entrepreneurship plays a vital role in the economic development of a country. Economic development of a country depends primarily on its entrepreneurs. An entrepreneur is very often considered a person who sets up his own business or set up his own industry. Women entrepreneurs may be defined as the women or a group of women who initiate, organize and operate a business enterprise. Empowering women particularly in Tribal Community has emerged as an important issue in recent times. The economic empowerment of women is a vital element of strong economic growth in a country. Entrepreneurship happens to be one of the best ways towards self sufficiency and poverty alleviation for women in a country where employment is not guaranteed. Involvement of women in entrepreneurial activities would ensure effective utilization of labour, generation of income and hence improvement in quality of life. Economic empowerment of women by entrepreneurial activities led to the empowerment of women in many things such as socio-economic opportunity, property rights, political representation, social equality, personal right, family development, community development and at last the nation development.

\section{Entrepreneurial Activity and Tribal Women in BTAD area of Assam:}

Bodoland Territorial Area District (BTAD) is the latest regional tribal development area constituted under a special enactment of the constitution of India.Bodoland Territorial Council is the outcome of an Agreement reached at among the Government of India and Government of Assam and the Bodo Liberation Tigers in February 10, 2003.Bodos are a traditional tribal ethnic group in Assam primarily concentrated in the Bodoland area. With the formation of the BTC(Bodoland Territorial Council ) a new vistas of development has begun in BTAD (Bodoland Territorial Area District) area.BTC is now preparing the Bodoland Territorial Area Development Plan and the Central Government sanctioned funds for the development of the area.BTC is a para -state administrative body with its separate Executive Council and Administrative staffs. The total area of Bodoland is approximately, stands at 8300 square K.M. comprising 3110 villages. There are four Districts in BTAD viz : Kokrajhar, Chirang, Baska and Udalguri.The BTAD was created under the sixth schedule of the constitution of India. At present Kokrajhar town serve as the headquarter of Bodoland.

In BTAD area out of total women population only $10 \%$ has engaged in earning. If the area in which the women of BTAD are skilled, is to be developed and necessary initiative need to be taken for proper training, providing equipment, creating market for the product, facilitating fund and then the unutilized resources can be brought to use at its height. Generally, in Tribal community women are very active and work hard in have with the male for the family. They mainly depend on agricultural practices for their livelihood. In compared to agricultural practices the percentage of job holding people are very less. Now-a-days few of them have started business. Women do hard work in agricultural practices as the males and help them for uplifting the economic condition of the family. They also rear domestic animals and weaves clothes. It is seen that some of them weave clothes by using modern methods of the technology and earn money for selling them .But one drawback of them is that they are not educated up to the mark to cope with the modern society. We know that illiteracy is the barrier for development of a society. Empowerment of women has been recognized as the key route for the development of any society, particularly in case of agrarian societies where women have often been neglected and their productive capacity has remained unutilized and underutilized. Therefore, this paper tries to deals with the entrepreneurial opportunities for tribal women and advantages of entrepreneurship among the tribal women and through the entrepreneurial activity how can increase the socio-economic status of the tribal women and empowering them. The tribal women in BTAD have inherent skills and expertise in making beautiful handicraft item with locally available raw materials like thread, jute, straw, wood, paper etc.But these products are not got the proper marketing facility. If such sector given the proper importance from the government and if we are able to create the awareness among the people then it increase the socio-economic status of the tribal women and empowering them economically. The following are the list of identifies entrepreneurial opportunities for tribal 
women in India, which has help to solve the problems of unemployment and proper utilization of both human and non-human resources and improving the living condition of the poor masses in rural India. The following identifies entrepreneurial opportunities are more beneficial for women in tribal community of BTAD area which enables them to add to the family income while taking care of their own home and increased the standard of living of the people of this region.

\section{Proposed Entrepreneurial Activity for Tribal Women in BTAD area:}

In Indian context, women entrepreneurship is a revolutionary concept. It provides many good to the women, the family and the society as a whole. The following are the list of identifies entrepreneurial opportunities for women in BTAD, Which has help to solve the problems of unemployment and proper utilization of both human and non-human resources and improving the living condition of the poor masses in BTAD area. The following identifies entrepreneurial opportunities are more beneficial for women in rural areas as it enables them to add to the family income while taking care of their own home and increased the standard of living of the rural people of BTAD area.

1. Micro enterprise development related to agriculture and allied agricultural activities like cultivating to natural vegetables, flowers, oil seeds and seed production are some of the areas besides taking up mushroom growing and bee -keeping. Some more areas like dehydration of fruits and vegetables, food preparation and preservation, Canning or bottling of pickles, chutneys, jams, dairy and other products those are ready to eat are prepared from such type of agricultural products. we have seen that tribal women are more active for producing such type of products, but they have prepared only for their own consumption. So our aim is to create the awareness among them that such product have lots of demand in market and give them proper marketing facility than it has increase the economic condition of such type of people.

2. Micro enterprise development related to livestock management activities like dairy farming, poultry farm , livestock feed production and production of using the animal waste can be an important area in which tribal women can utilize both her technical skills and raw materials from the farm and livestock to earn substantial income and small scale agro-processing units. Because now-a-days such type of commodity have lots of demand in the market.

3. Micro enterprise development related to household based operations like knitting, stitching, weaving and embroidery, create handicraft and handcrafted gift items, embroidery from thread etc. Such type of handloom product has lots of demand all over the world. We have seen that tribal women are producing various types of handloom products. So, our aim is to encourage them to produce such type product and diversifying their products and give them proper marketing facility.

4. Identification of natural entrepreneurial skill for tribal women: Business opportunities for women folk comprise of using metals, wood, stone and metal like iron, steel to create handicrafts and hand-crafted gift items such as metal items, cane and bamboo making furniture, clay for making statues, pots, vessels, other decoration pieces, making basket from straw, carpet making through jute and other waste material .If we are properly able to develop such type of industry then certainly it will change the economic condition of the tribal community.

5. Employment opportunity for tribal women in Small Scale Sector: Small scale sector in India over the past 50 years has made significant contribution towards building a strong national economy. The government also taking initiatives by providing various types of incentives and subsidies to the small scale industries for improving their economic condition and also providing employment, thereby increasing the standard of living of the rural masses. The tribal women have immense potential and expertise in art and craft, handloom, food products like papad, pickles, clay utensils, bamboo baskets etc. Small scale unit create more self-employment opportunities with less capital investment requirements, the raw materials are locally based and there is less environmental pollution. Small firms require simple technology and low managerial skills.

6. Allied Activities: The following are list of business opportunities for tribal women in rural India like floriculture, seed production, Mushroom production, Bee-Keeping, processing of milk, Dairy products, Agro processing, Coir work, Toy making with different types of raw material, Leather handicraft, Agarbatti ,Chalk, Candle ,Jute bag etc.

7. Women in Rural Retailing: Another area which is full of opportunities for rural women is selling low cost economical branded products in rural areas so that branded products can reach the remote places. These 
women know the local language, identify the needs and requirements, tastes and preferences of rural population. The objective of the project was to create source of incomes for underprivileged rural women, thereby improvement in their standard of living, better education for their children, better health.

8. Alcohol Industry: Another important area where tribal women can create their employment opportunity is liquor industry. In India as well as Assam has produced large varieties of fruits. So on the basis of this fruits they have greater potentiality to set up liquor industry and beverages industry. Because we have seen that the tribal women have lots of experience in this sector because of their own consumption they have to produce such type of products in traditionally.

\section{Role of Government for developing entrepreneurial activity among Tribal Women:}

Empowering women particularly rural women is a challenge. Entrepreneurial activities in rural area can help to meet these challenges. Entrepreneurial activities not only enhance national productivity, generate employment but also help to develop economic independence, personal and social capabilities among rural women. Economic empowerment of women by entrepreneurship led to the empowerment of women in many things such as socio -economic opportunity, property rights, political representation, social equality, personnel right, family development, market development, community development and at last the nation development. Increased participation of women in the labour force is a prerequisite for improving the position of women in society and self employed women. Particularly the entry of tribal women in entrepreneurial activities will be encouraged and motivated. Tribal women can do wonders by their admired and competent involvement in entrepreneurial activities. The rural woman has basic indigenous knowledge, skill, potential and resources to establish and manage enterprise. Now, what is the need is knowledge regarding accessibility to loans, various funding agencies procedure regarding certification, awareness on Government welfare programme, motivation, technical skill and support from family, government and other organization. Moreover formation and strengthening of rural women entrepreneurs' network must be encouraged. This network helps to give lectures, printed material imparting first hand technical knowledge in production, processing, procurement, management and marketing among other women. This will motivate other rural women to engage in micro entrepreneurship with the right assistance and they can strengthen their capacities besides adding to the family income and national productivity.

Therefore, the New Industrial Policy of Government of India has stressed the importance of entrepreneurship among women .This policy concedes that merely making larger resource allocation for women within the prevailing pattern and structure of development would not yield the desired results. The policy has a strategy for the holistic development of women. This would help develop their personality and at the same time improve their social and economic conditions. The Indian tribal women entrepreneur thus has the ideal climate for exhibiting her talents. The Government does have the responsibility to improve the lot of women in economic life and prepare them to participate in industrial estates as entrepreneurs. It is essential that Indian tribal women must be ready to overcome their own limitations. It is essential that Indian tribal women must be ready to reach out for new jobs, new responsibilities and new experiences.

Good Entrepreneur can create a strong economy. Entrepreneurship is an important feature of industrial growth and development of a nation. It is the backbone of a nation that sets its eyes on maximizing its performance in every field. The spirit of entrepreneurship brings about enthusiasm, persistence and the ability to seek entrepreneurial opportunities that lead to success. A nation's ability to generate a steady stream of business opportunities can only come about when its people take to entrepreneurial activities. Entrepreneurs are essentially the engines of growth for a nation. There are several factors that go into making a successful entrepreneur, and he or she need not necessarily possess a strong business and financial background. On the contrary, well-conceived and well directed training can always produce an outstanding entrepreneur. Therfore,in the recent times the state government as well as central government has taken various policy to improve the economic condition of the tribal community. But due to the lack of information and proper guidance they are not able to get the benefit. Therefore, tribal women must be educated and for this awareness should be raised among them through the literacy programme.This will increase the percentage of educated people and will help in uplifting the socio-economic standard of the society and empowering the women. Women empowerment may mean equal distribution of socio-economic power between men and women. Empowering women is the empowering nation. This paper aims at highlighting the participation of tribal women in changing the social and economic scenario in tribal community and some measures to improve the status of tribal women.

Therefore, the government policy makers are reevaluating strategies on development of women entrepreneurship where the role of education and training in the development of rural women entrepreneur is of crucial importance. It helps to create a capable women labour force and maintain a skilled worked force in the area by providing skills that would help to upgrade the existing business like Eri , Pat and Muga silk and to start a modern business venture. The government should provide link with other educational institution outside the 
rural area in order to bring technical expertise available outside the area and provide adequate knowledge about banking procedures and various schemes of the government which are meant to develop women entrepreneurship. The government should also conduct various training programme especially for women entrepreneur to remove their ignorance about latest technology and knowhow and to understand present market situation. Instead of this institution like business incubator, different NGO's can play major role in the development of women entrepreneurship in BTAD areas.

\section{Conclusion:}

Promotion of tribal women entrepreneurs requires a multipronged approach. Tribal Women should be motivated to come out of their traditional occupation for accepting more challenging and rewarding economic activities. Concurrently an environment should be arranged to enable their participation. Primarily, this would necessitate motivating funding agencies to be sympathetic towards to entrepreneurship. The other promotional and regulatory agencies should also be motivated to be considerate, understanding and helpful towards women entrepreneurs. In India several institutional arrangements have been made to protect and develop women entrepreneurship .The nationalized banks and state Financial Corporations, NABARD, SIDBI and District Industries Centre's provide loans to women entrepreneurs on preferential basis. It has also suggested that instead of giving priorities, a certain percentage be reserved for tribal women in the various self employment schemes, and that special institutions are set up at the State -level to help them to upgrade their skills and acquire technomanagerial knowledge so that they could go in for innovative technologies of production. Among other things, the team has stressed the need for educational institutions, particularly women's colleges and universities, to conduct training programs in entrepreneurship development and for establishing industrial estates and marketing complexes exclusively for women entrepreneurs. With the advent of new economic policies - with liberalization, privatization, and globalization as their major thrust - the environment can create new vistas for entrepreneurship development. Promoting and encouraging competitive growth oriented and quality conscious entrepreneur is the need of the hour now. To make them think globally and operate efficiently is of utmost importance. Hence, there is a need to formulate policies, which aim for the empowerment of women through various types of entrepreneurial activity because when women move forward, the family moves, the villages' moves and the nation moves. That is why; we must have given the importance of development entrepreneurial activity among the tribal women in BTAD area of Assam. Entrepreneurship can help rural women's economic interdependence and improve their social status.

\section{References:}

[1]. S.S. Khanka - Entrepreneurship in India perspective and Practice - Akansa Publishing House , New -Delhi ,2009

[2]. Dr. Bhawan Bhatnagar , Ankur Budhiraja - Small Business Management -Vayu Education of India ,New Delhi ,2009

[3]. Misra and Puri -Indian Economy -Kalyani Publishers, New -Delhi , 2009

[4]. Alpana Trechan -Entrepreneurship -Dramatic Press -New-Delhi, 2012

[5]. C.S Prasad, V Mathur and A.Chatterjee -Sixty Years of Indian Economy (1947 to 2007) -New Century Publications, 2007 ,New Delhi

[6]. R.P.Kachru -Agro -Processing Industries in India -Growth ,Status and Prospects

[7]. Statistical Handbook of Bodoland -2012 - Department of Economics and Statistics

[8]. D.D.Mali -Micro Enterprise Development Development Policies and Programmes -IIE ,Guwahati.2001

[9]. Sinha ,Poonam -Women Entrepreneurship Development in North East -IIE ,Guwahati , 2000

[10]. Amalesh Chandra Banarjee and Sourav Singh Roy - Problem and Prospect of Bodoland - A Mittal Publication , New -Delhi ,2010

[11]. Ram Krishna Mandal - Entrepreneurship and Rural Development in North East India -DVS Publishers ,2011 , Guwahati 